\title{
Respuesta al tratamiento con eltrombopag en pacientes con púrpura trombocitopénica inmune (PTI) en un servicio de hematooncología (SHO), Cali
}

Objetivo. Evaluar la respuesta al tratamiento con eltrombopag en pacientes con PTI en un SHO, Cali.

Materiales y métodos. Estudio descriptivo, tipo serie de casos. Se revisaron 13 historias clínicas de pacientes con eltrombopag, dosis inicial 50 mg/día, ajustado acorde evolución. Se caracterizaron variables clínicas y paraclínicas para evaluar respuesta al tratamiento, y los posibles efectos adversos. Se definió como respuesta recuento plaquetario (RP) mayor a 30.000 o que presente incremento de por lo menos dos veces el valor basal.

Resultados. Se encontró edad promedio 62,3 años (rango: 25-86 años), el $42,9 \%$ fueron mujeres. Antes de iniciar tratamiento, estos pacientes llevaban en promedio 34,4 meses desde el diagnóstico de PTI (rango: 1-132 meses). El 38,4\% no tenían antecedentes de importancia, el 30,7\% tenían hipertensión arterial, el 23,0\%, diabetes mellitus; un paciente tenía hipotiroidismo controlado.

Todos recibieron tratamientos previos: el $84,6 \%$ esteroides, el $61,5 \%$ inmunoglobulina anti-D, el 15,3\% esplenectomía, el 30,7\% danazol, de los cuales un paciente además recibió azatioprina. Otro recibió ciclofosfamida. El 38,4\% (5 pacientes) tuvieron tratamiento concomitante: 3 pacientes esteroides, otro azatioprina y uno fue sometido a esplenectomía (a pesar de haber alcanzado respuesta).
El RP antes de eltrombopag fue en promedio 22.846 plaquetas/ul (rango: 6.000-43.000 plaquetas/ul). En el primer mes, el 69,2\% tuvo respuesta. Un paciente suspendió tratamiento a las dos semanas por efectos adversos. En el segundo y cuarto mes, otros dos pacientes obtuvieron respuesta. La respuesta se mantuvo a lo largo del seguimiento (promedio seguimiento: 14,5 meses), excepto en dos pacientes, debido a que dejaron de obtener respuesta en el segundo y cuarto mes, respectivamente.

Antes de eltrombopag, 6 pacientes tuvieron manifestaciones hemorrágicas en piel y 4 presentaron sangrado en mucosas. Después del tratamiento, las manifestaciones hemorrágicas desaparecieron, excepto un paciente que presentó gingivorragia.

Un paciente tuvo alteración en pruebas hepáticas, emesis y alopecia; 4, cefalea; 2, osteomioartrialgias.

Conclusión. El eltrombopag obtuvo en nuestra población una buena respuesta, similar a la reportada en la literatura internacional, la cual se sostuvo en el tiempo en la mayoría de pacientes, con adecuada tolerancia, excepto una paciente que suspendió el tratamiento por efectos adversos.

\section{Complications associated with PICC insertion in a hospital for high level of complexity of the city of Medellín (Colombia)}

\author{
- S. Roldán, F. Combariza, K. Gálvez, V. Palacios, V. Olaya, L. Ballesteros
}

Hospital Pablo Tobón Uribe.

Objective. To identify the complications related with peripherally inserted central catheter (PICC).

Methods. It study was conducted a retrospective observational-cutting between the months of January 2011 to November 2011. We analyzed data from 200 patients who underwent insertion of a PICC between the dates described above and looked at the variables associated such as: complications, length of stay of the PICC, sex and indications for PICC.

Results. In this study of 200 patients found a median age of 42.4 years, 105 patients were male and 95 female $(52.5 \%$ and $47.5 \%$ respectively), 22 IPCC presented infectious complication for $11 \%$ of PICC collected: 6 infections caused by Klebsiella spp. (3\%), 5 Sthaphylococus spp. infections (2.5\%), 4 Proteus spp. infections (2\%), 6 Escherichia spp. infections (3\%) and 1 infection by Pseudomonas spp. $(0.5 \%)$ and thrombotic events were $2(1 \%)$. The indications PICC placement were difficult venous access 53 catheters $(26.5 \%)$, chemotherapy 55 catheters (27.5\%), TPN 26 catheters (13\%), prolonged antibiotics 41 catheters (20.5\%), hypokalemia 7 catheters $(3.5 \%)$, no data 8 catheters $(4 \%)$, other 10 catheters $(5 \%)$. The average days of stay were 29 days PICC.

The PICC presented complications were removed in average 40 days of insertion and only 3 of them before day 10, mortality complications associated with PICC insertion was $0.0 \%$.

The PICC remained between 2 and 176 days depending on the patient and the indication for placement.

Conclusion. Data suggest that the complications associated with PICC insertion are more than $10 \%$ prevalence. Infectious complications being the most frequently encountered in our center. It also shows that the PICC catheter stay exceeding 10 days is a clearly identified risk factor for the submission of such complications, and despite being a high number of complications evidenced no association with mortality in this group of patients. 